DOI: $10.19195 / 0080-3626.60 .6$

MARIA JUDA

\title{
POWOJENNE POLSKIE BADANIA NAD HISTORIA RUCHU WYDAWNICZEGO W POLSCE: DOROBEK I POSTULATY BADAWCZE
}

Obszary tematyczne w polskim dorobku publikacyjnym dotyczącym dziejów ruchu wydawniczego. Analiza publikacji poświęconych historii drukarstwa i działalności typograficznej, a także zjawiskom kształtującym charakter i strukturę produkcji wydawniczej oraz problemom odnoszącym się do dziejów samej książki jako wytworu pracy drukarza i wydawcy. Publikacje informacyjne (bibliografie i katalogi), których zadaniem jest rejestracja polskiej produkcji drukarskiej.

SŁOWA KLUCZOWE: bibliologia, bibliologia historyczna, historia książki, drukarstwo, ruch wydawniczy, edytorstwo

Trwający przez dziesięciolecia proces kształtowania się nauki o książce, eksponując różne obszary, metody i perspektywy badawcze, doprowadził do objęcia kompetencjami księgoznawczymi pełni procesu komunikacji społecznej realizowanej za pośrednictwem zapisu graficznego, utrwalonego na dowolnym rodzaju nośników pierwotnych i wtórnych wykorzystywanych w przeszłości, obecnie i w przyszłości ${ }^{1}$. Głównym jej „obiektem jest książka i procesy bibliologiczne: tworzenie, obieg i odbiór książki, lecz także skutki tych procesów oraz ludzie i instytucje w nich uczestniczące", jednak przedmiotem badań tego obiektu są tylko te zjawiska, „które dotyczą kulturowych i społecznych aspektów i funkcji książki"2.

Tak jak i inne dyscypliny nauka o książce kształtowała się poprzez stopniowe poszerzanie pola badawczego celem uchwycenia możliwie wszystkich problemów życia i funkcjonowania książki oraz precyzowania jej zakresu i eliminowania

1 Zob. m.in. Krzysztof MIGOŃ, Nauka o książce. Zarys problematyki, Wrocław: Zakład Narod. im. Ossolińskich 1984, 319 s.; idem, O nazwie dyscypliny, która uprawiamy, Przegląd Biblioteczny (61) 1993, z. 1/2, s. 109-113; idem, Bibliologia - nauka o kulturze ksiązki, Nauka 2005, nr 2, s. 49-57.

2 K. MIGOŃ, Nauka o książce..., s. 108-109. 
tego, co do niej nie należy. Mimo dużych osiągnięć w tej dziedzinie w dalszym ciągu wiele kwestii wymaga dookreślenia, a na taki stan rzeczy wpływa niewątpliwie fakt, że bibliologia charakteryzuje się wieloma paradygmatami badawczymi.

Wieloaspektowość i wielokierunkowość badań doprowadziły do wyodrębnienia się licznych dyscyplin zajmujących się oddzielnymi elementami książki i różnymi aspektami procesów bibliologicznych, rozpatrywanymi zarówno w kontekście historycznym, jak i współczesnym. Można zatem mówić o problemach księgoznawstwa historycznego oraz współczesnego. W ich obszarach znajduje się wiele kwestii wpisujących się w zagadnienie ruchu wydawniczego.

Jedną z dziedzin historycznego księgoznawstwa jest historia drukarstwa, obejmująca zazwyczaj dzieje edytorstwa, formy książki i jej wyposażenia artystycznego, polem zaś jej badań jest działalność typograficzna, jej techniczne, ekonomiczne i społeczne uwarunkowania, funkcjonowanie oficyn typograficznych oraz ich repertuar wydawniczy. Na współczesny system książki składa się także edytorstwo, którego przedmiotem są procesy tworzenia i produkcji książki, z pominięciem jednak ich aspektu technicznego. Uwaga kierowana jest też na programowanie i prognozowanie wydawnicze, które bierze pod uwagę zarówno zapotrzebowanie czytelnicze odbiorców, jak i wywoływanie oraz kształtowanie nowych zainteresowań. Nie można pomijać zagadnień odnoszących się do właściwego, ukierunkowanego na czytelnika ukształtowania i wyposażenia wydawanych książek. Wiele problemów o charakterze teoretycznym i praktycznym składa się na zakres i charakter pracy wykonywanej nad autorskim tekstem przez redaktora - wydawcę. Na książkę jako twór artystyczny kieruje uwagę sztuka książkowa ${ }^{3}$. Ostatnie lata poszerzyły obszar edytorstwa o zagadnienia odnoszące się do zastosowania w procesie publikacyjnym nowoczesnych technologii informatycznych i informacyjnych.

Historiografia ruchu wydawniczego niejednokrotnie poddawana była retrospekcji, analizie i ocenie. Szczególną uwagę kierowano na dzieje dawnego drukarstwa. Zygmunt Mocarski ${ }^{4}$, Helena Więckowska ${ }^{5}$, Alodia Kawecka-Gryczowa ${ }^{6}$,

3 Ibidem, s. 140-141, 189-195.

4 Zygmunt MOCARSKI, Stan badań polskiego drukarstwa, [do druku przygot. i przedm. Janina Huppenthal], Toruń: Wojewódzka Biblioteka Publiczna i Książnica Miejska im. M. Kopernika 1985.

5 Helena WIĘCKOWSKA, Organizacja, stan i kierunki badań bibliologicznych 1945-1967, Przegląd Biblioteczny (36) 1968, z. 1/2, s. 45-77.

6 Alodia KAWECKA-GRYCZOWA, Dzieje drukarstwa w Polsce XV i XVI wieku. Stan badań i postulaty, [w:] Dawna ksiązka i kultura. Materiaty międzynarodowej sesji naukowej z okazji pięćsetlecia sztuki drukarskiej w Polsce. Praca zbiorowa pod red. Stanisława Grzeszczuka i A. Kaweckiej-Gryczowej, Wrocław: Zakład Narod. im. Ossolińskich 1975, s. 9-32. 
Henryk Bułhak ${ }^{7}$, Jan Pirożyński ${ }^{8}$ czy Paulina Buchwald-Pelcowa ${ }^{9}$ pokazali nie tylko osiągnięcia w tej dziedzinie, lecz także wskazali na braki i wyznaczyli kierunki dalszych działań.

Badania w tej dziedzinie niemal każdego roku przynosiły kolejne dokonania wypełniające dotychczasowe luki. Warto zatem przyjrzeć się ich kierunkom i poddać je krytycznej ocenie.

Istotną - jeśli nie podstawową — rolę w warsztacie badacza dziejów drukarstwa i ruchu wydawniczego odgrywają materiały źródłowe. Ich ewidencjonowanie, gromadzenie, opracowywanie i krytyczna edycja jest koniecznym warunkiem rozwoju wiedzy o dokonaniach w tym zakresie. Dynamiczny rozwój nauki o książce w dwudziestoleciu międzywojennym zaowocował wieloma publikacjami źródłowymi. Działania te niestety nie znalazły pełnej kontynuacji w latach powojennych. Wypada zgodzić się w opinią Anny Żbikowskiej-Migoń, że „w zakresie źródłoznawstwa bibliologicznego dokonano i dużo, i mało zarazem" ${ }^{10}$. Szczególnie odczuwa się brak publikacji źródłowych samoistnych wydawniczo. Dobrze zatem się stało, że ukazały się reprinty ważnych dla badacza dzieł Teodora Wierzbowskiego i Jana Ptaśnika ${ }^{11}$. Nowym dokonaniem w tym zakresie jest edycja przywilejów drukarskich Marii Judy ${ }^{12}$. Na uwagę zasługuje, niestety przerwana, kontynuacja dzieła Kazimierza Piekarskiego Polonia typographica saeculi sedecimi, której kolejne zeszyty zawierają dokumentację dorobku wydawniczego i zasobu typograficznego szesnastowiecznych oficyn drukarskich ${ }^{13}$. Wiedeńskiemu dorobkowi Hieronima Wietora podobne

${ }^{7}$ Henryk BUŁHAK, Badania nad dziejami książki polskiej wieków XVI-XVIII w okresie powojennym, cz. 1, Rocznik Biblioteki Narodowej (4) 1968, s. 333-357.

8 Jan PIROŻYŃSKI, Z badań nad drukarstwem XV wieku. Przegląd nowszych publikacji, Studia Historyczne (16) 1971, z. 4, s. 563-577.

9 Paulina BUCHWALD-PELCOWA, Badania nad historia polskiej książki drukowanej XVXVIII wieku, Przegląd Biblioteczny (42) 1974 [druk 1975], z. 4, s. 371-390.

10 Anna ŻBIKOWSKA-MIGOŃ, Wydawnictwa źródłowe do dziejów książki w Polsce. Stan i potrzeby, Studia o Książce (15) 1985, s. 43.

11 Teodor WIERZBOWSKI, Materiaty do dziejów piśmiennictwa polskiego i biografii pisarzów polskich. T. 1-2, Warszawa: Wydaw. Artystyczne i Filmowe [1978 reprint]; Jan PTAŚNIK, Cracovia impressorum XV et XVI ss. Warszawa: Wydaw. Artystyczne i Filmowe [1979 reprint].

12 Privilegia typographica Polonorum. Polskie przywileje drukarskie 1493-1793. Oprac. i wyd. Maria Juda, Lublin: Wydaw. UMCS 2010.

13 Polonia typographica saeculi sedecimi. Zbiór podobizn zasobu drukarskiego tłoczni polskich XVI stulecia. Pod red. Alodii Kaweckiej-Gryczowej, z. 1-12. Wrocław: Zakład Narod. im. Ossolińskich 1959-1981. Z. 1. Kasper Hochfeder. 1503-1505, wyd. 2 uzup. Oprac. Maria Błońska, 1968. Z. 2. Jan Haller. 1505-1525, wyd. 2. Oprac. Helena Kapełuś, 1963. Z. 3. Pierwsza drukarnia Floriana Unglera. 1510-1516. Oprac. Henryk Bułhak, 1959. Z. 4. Jan Haller. 1505-1525. Oprac. H. Kapełuś, 1962. Z. 5. Druga drukarnia Floriana Unglera. 1521-1636. Oprac. H. Bułhak, 1964. Z. 6. Druga drukarnia Floriana Unglera. 1521-1536. Oprac. H. Bułhak, 1966. Z. 7. Druga 
opracowanie poświęcił Henryk Bułhak ${ }^{14}$. Ważnym dla badacza ruchu wydawniczego osiągnięciem jest także edycja dotyczących książki osiemnastowiecznych ogłoszeń prasowych ${ }^{15}$. Skromny dorobek należy odnotować w zakresie edycji źródeł do dziejów ruchu wydawniczego doby zaborów i Polski odrodzonej. Nie mogą tej luki wypełnić wyciągi źródłowe Mariana J. Lecha ${ }^{16}$.

W badaniach nad dziejami drukarstwa zasadnicze znaczenie ma pełna rejestracja produkcji drukarskiej. W tego rodzaju postępowaniach badawczych książka jest bowiem zarówno przedmiotem badań, jak i źródłem wiedzy. Pełne rozpoznanie stanu produkcji wydawniczej pozwala na uzyskanie odpowiedzi na gamę pytań wpisujących się w badania nad dziejami kultury książki, przede wszystkim odnoszących się do jej produkcji, lecz także w pewnym zakresie — jej rozpowszechniania i uży tkowania oraz książki jako wytworu kultury materialnej, duchowej i narzędzia społecznego komunikowania. Pozwala nie tylko na poznanie geografii wydawniczej na ziemiach polskich w zmieniającym się terytorium państwa, w różnych warunkach politycznych, społecznych, gospodarczych, wyznaniowych i kulturalnych, lecz także na rozpoznanie i analizę polityki wydawniczej władz państwowych, kościelnych czy miejskich. Jest również źródłem do określenia stopnia zaspokojenia przez polskie instytucje wydawnicze zapotrzebowań czytelniczych polskiego użytkownika książki, oryginalności oferty wydawniczej, jej otwartości na obcy dorobek piśmienniczy, popularności pewnych wydawnictw i tym podobnych zjawisk.

Dla badacza podejmującego problemy dziejów ruchu wydawniczego na ziemiach polskich fundamentalne znaczenie ma Bibliografia polska Estreichera, jak dotąd niezastąpiona pod względem bogactwa i zakresu zgromadzonego materiału. Co prawda ma ona pewne luki, a dla części staropolskiej w dalszym ciągu brakuje kontynuacji litery Z, jednak rośnie liczba nieznanych Estreicherowi edycji dzięki pracom nad zasobami starodruków w różnych polskich księgozbiorach hi-

drukarnia Floriana Unglera. 1521-1536. Oprac. H. Bułhak, 1970. Z. 8. Aleksander Augezdecki. 1549-1561. Oprac. Paulina Buchwald-Pelcowa, 1972. Z. 9. Maciej Wirzbięta. 1555/7-1605. Oprac. A. Kawecka-Gryczowa, 1974. Z. 10. Maciej Wirzbięta. 1555/7-1606. Oprac. A. Kawecka-Gryczowa, 1975. Z. 11. Maciej i Pawet Wirzbiętowie 1555/7-1609. Oprac. A. Kawecka-Gryczowa, 1981. Z. 12. Maciej Szarfenberg. 1527-1547. Oprac. H. Bułhak, 1981.

${ }^{14}$ H. BUŁHAK, Wiedeńska oficyna Hieronima Wietora. Materiały do dziejów zasobu typograficznego oraz bibliografii druków z lat 1510-1518, [w:] Z badań nad dawną książka. Studia ofiarowane profesor Alodii Kaweckiej-Gryczowej w 85-lecie urodzin. Cz. 2, Warszawa: Biblioteka Narodowa 1993, s. 297-431.

15 Ksiązka w ogłoszeniach prasowych XVIII wieku. Oprac. Stanisław Grzeszczuk, Danuta Hombek. T. 1. Wrocław: Wiedza o Kulturze 1992. T. 2-5. Kraków: Universitas 1995-2005. T. 6. Oprac. D. Hombek, Kraków: Universitas 2016.

${ }_{16}$ Marian J. LECH, Drukarze i drukarnie w Królestwie Polskim 1869-1905. Materiały ze źródet archiwalnych, Warszawa: Biblioteka Narodowa 1979. 
storycznych ${ }^{17}$. Owocne okazało się też wykorzystanie źródeł dokumentacyjnych odnoszących się do dziejów oficyn typograficznych ${ }^{18}$.

Uzupełnieniem do Bibliografii Estreichera są też prace bibliograficzne poświęcone określonym typom wydawnictw, wydaniom dzieł ważnych przedstawicieli polskiej literatury i nauki, oficynom wydawniczym oraz dorobkowi typograficznemu miejscowości. Szczegółowy wykaz tego rodzaju dokonań wymienionych w opracowaniach z lat 1968 i 1975 H. Bułhaka i A. Kaweckiej-Gryczowej ${ }^{19}$ należałoby uzupełnić - między innymi — o dzieła rejestrujące dorobek wydawniczy miast ${ }^{20}$ oraz o pogłębione studium P. Buchwald-Pelcowej poświęcone staropolskim wydaniom dzieł Jana Kochanowskiego ${ }^{21}$.

Obraz staropolskiego dorobku wydawniczego wzbogacają też publikowane katalogi dawnych wytworów sztuki typograficznej. Szczególne znaczenie dla badań bibliologicznych ma rejestracja inkunabułów. Swoistym podsumowaniem tego rodzaju działań było ukazanie się opracowanego w Bibliotece Narodowej centralnego katalogu inkunabułów zachowanych w polskich zbiorach ${ }^{22}$. Kolejne lata przyniosły dalsze prace autorstwa - między innymi — Jolanty M. Marszalskiej, Jolanty Ociepy, Wiesława Wydry, Jana Obłąka, Zoi Jaroszewicz-Pieresławcew i Juliana Wojtkowskiego oraz Janusza Tondela ${ }^{23}$. Światło dzienne ujrzało też wiele

17 M.in.: Albina SIEMIEŃCZUK, Nieznane Estreicherowi wydania kronik polskich z XVXVIII wieku w zbiorach Muzeum Historyczno-Archeologicznego w Grodnie, [w:] Europa Orientalis. Pod red. Zbigniewa Karpusa, Tomasza Kempy, Doroty Michaluk, Toruń: Uniwersytet Mikołaja Kopernika 1996, s. 231-240; Bernadeta IWAŃSKA-CIEŚLIK, Osiemnastowieczne druki z Pomorza Gdańskiego i Warmii nieznane Estreicherowi w zbiorach Biblioteki Wyższego Seminarium Duchownego we Włocławku, Acta Universitatis Nicolai Copernici, Bibliologia (5) 2006, s. 171-189.

18 Joanna KRAUZE-KARPIŃSKA, Uzupetnienia do „Bibliografii polskiej” Estreichera na podstawie rękopiśmiennej księgi wpływów i wydatków warszawskiej Drukarni Misjonarzy, Rocznik Biblioteki Narodowej (37/38) 2006, s. 151-218.

19 H. BUŁHAK, Badania nad dziejami..., s. 350-351; A. KAWECKA-GRYCZOWA, Dzieje drukarstwa..., s. 14-15.

${ }^{20}$ Krystyna BIELSKA, Bibliografia starych druków kaliskich. Do końca XVIII w. Warszawa: PWN 1980; Jerzy SEKULSKI, Bibliografia druków elbląkich: 1558-1772, Warszawa: Wydaw. Ministerstwa Obrony Narodowej 1988; Irena DZIOK-STRELNIK, Bibliografia starych druków lubelskich 1630-1800, Lublin: Wojewódzka Biblioteka Publiczna im. H. Łopacińskiego 1997; Anna SICIAK, Druki przemyskie 1754-1939. Bibliografia publikacji polskich, niemieckich, francuskich oraz żydowskich i ukrainskich wydanych alfabetem łacińskim, Przemyśl: Południowo-Wschodni Instytut Naukowy w Przemyślu 2002.

${ }^{21}$ P. BUCHWALD-PELCOWA, Dawne wydania dziet Jana Kochanowskiego, Warszawa: PWN 1993.

22 Incunabula quae in bibliothecis Poloniae asservantur. T. 1. Moderante A. Kawecka-Gryczowa, composuerunt Maria Bohonos et Eliza Szandorowska. T. 2. Addenda, Indices, Moderante A. Kawecka-Gryczowa, composuerunt M. Bohonos, Michał Spandowski et E. Szandorowska, Wrocław: Zakład Narod. im. Ossolińskich 1970-1993. Wykaz katalogów zob. A. KAWECKA-GRYCZOWA, Dzieje drukarstwa..., s. 15.

${ }^{23}$ Katalog inkunabułów biblioteki Wyższego Seminarium Duchownego w Tarnowie. Oprac. Jolanta M. Marszalska, Tarnów: Wyższe Seminarium Duchowne w Tarnowie 1997; Katalog in- 
niesamoistnych wydawniczo tego rodzaju rejestrów. Niektóre dokonania krytycznej ocenie poddał Michał Spandowski ${ }^{24}$. O ile w przypadku katalogów J. Ociepy i W. Wydry zgłosił zastrzeżenia co do właściwych odczytów proweniencji, braku danych o mniej znanych postaciach, niekonsekwencji z nazwami miejscowości i usterek techniczno-redakcyjnych, nie negując jednak ich końcowego pozytywnego rezultatu, o tyle w odniesieniu do katalogu szczyrzyckiego jego oceny mają charakter nadzwyczaj krytyczny, i to o znaczeniu fundamentalnym. W opinii M. Spandowskiego występują w nim liczne błędy metodologiczne, terminologiczne i językowe, związane $\mathrm{z}$ wadliwym odczytaniem zapisów proweniencyjnych; brakuje też nowych ustaleń typograficznych ${ }^{25}$.

Nie można nie wspomnieć o katalogach starodruków przechowywanych w zasobach wielu bibliotek krajowych. Do wyszczególnionych w pracach A. Kaweckiej-Gryczowej czy H. Bułhaka należałoby dodać kolejne rejestry dotyczące nie tylko bibliotek o bogatych zasobach starodrucznych, takich jak Biblioteka Jagiellońska ${ }^{26}$, Biblioteka Uniwersytecka w Warszawie ${ }^{27}$, Biblioteka Publiczna m. st. Warszawy ${ }^{28}$, Biblioteka Uniwersytecka we Wrocławiu ${ }^{29}$, Biblioteka Ossolineum $^{30}$, lecz także mających skromniejsze tego rodzaju zbiory, jak biblioteka

kunabułów Biblioteki Opactwa OO. Cystersów w Szczyrzycu. Oprac. J.M. Marszalska, Kraków: Tyniec Wydaw. Benedyktynów 2002; Jolanta OCIEPA, Katalog inkunabułów Wojewódzkiej i Miejskiej Biblioteki Publicznej w Bydgoszczy. Bydgoszcz: Wojewódzka i Miejska Biblioteka Publiczna w Bydgoszczy 1999; Wiesław WYDRA, Katalog inkunabułów Biblioteki Uniwersyteckiej w Poznaniu, Poznań: Uniwersytet im. Adama Mickiewicza 2002; Jan OBŁĄK, Zoja JAROSZEWICZ-PIERESŁAWCEW, Julian WOJTKOWSKI, Katalog inkunabutów biblioteki Wyższego Seminarium Duchownego Metropolii Warmińskiej „Hosianum” w Olsztynie, Olsztyn: Wydaw. Uniwersytetu Warmińsko-Mazurskiego 2007; Janusz TONDEL, Inkunabuły w zbiorach Wyższego Seminarium Duchownego w Pelplinie, Toruń: Wydaw. Uniwersytetu Mikołaja Kopernika 2007.

${ }^{24}$ Michał SPANDOWSKI, Uwagi o polskich katalogach inkunabułów, Rocznik Biblioteki Narodowej (37/38) 2006, s. 351-402. Tam też przegląd innych polskich katalogów.

25 M. Spandowski, Polskie zbiory inkunabułów zniszczone, rozproszone i przemieszczone w czasie i w wyniku II wojny światowej, Rocznik Biblioteki Narodowej (44) 2013, s. 5-36.

${ }^{26}$ Katalog poloników XVI wieku Biblioteki Jagiellońskiej. T. 1-3. Catalogus librorum polonicorum saeculi XVI qui in Bibliotheca Iagellonica asservantur. Pod red. Mariana Malickiego. T. 1-3, Kraków: Uniwersytet Jagielloński 1991-1995.

27 Katalog druków XV i XVI wieku w zbiorach Biblioteki Uniwersyteckiej w Warszawie. T. 1-5. Pod red. Haliny Mieczkowskiej, Warszawa: Wydaw. Uniwersytetu Warszawskiego 19942015 .

${ }^{28}$ Katalog starych druków Biblioteki Publicznej m. st. Warszawy. Cz. III. Polonica XVII wieku. Oprac. Jadwiga Rudnicka, Warszawa: PWN 1976.

29 Jan Bolesław OŻÓG, Katalog poloników XVI wieku Biblioteki Uniwersyteckiej we Wrocławiu. T. 1-2, Wrocław: Wydaw. Uniwersytetu Wrocławskiego 1988-1991.

${ }^{30}$ Katalog starych druków Biblioteki Zakładu Narodowego im. Ossolińskich: polonica wieku XVII. Oprac. Barbara Górska i Wiesław Tyszkowski. T. 1-9, Wrocław: Zakład Narod. im. Ossolińskich 1991-1997. 
Poznańskiego Towarzystwa Przyjaciół Nauk czy Sądecka Biblioteka Publiczna ${ }^{31}$. Do dyspozycji badaczy pozostaje również wymagający nieustannych korekt i uzupełnień centralny katalog starych druków Biblioteki Narodowej ${ }^{32}$.

Wiele korzyści w tym zakresie przyniosły eksploracje badawcze nad polonikami przechowywanymi w bibliotekach zagranicznych. Ważnym sygnałem w tym względzie były kwerendy prowadzone jeszcze na początku ubiegłego stulecia w Szwecji ${ }^{33}$, wzbogacone później badaniami Czesława Pilichowskiego ${ }^{34}$, a przede wszystkim Józefa Trypućki ${ }^{35}$. W ostatnich latach ukazały się kolejne tego rodzaju opracowania, weryfikujące i uzupełniające dotychczasowy stan badań ${ }^{36}$. Istotne jest, że nie ograniczyły się one do tego kierunku poszukiwań, lecz objęły również inne, często odległe obszary. Na uwagę zasługują nie tylko przytaczane w literaturze, a ukierunkowane na zbiory amerykańskie dokonania Janiny Wójcickiej Hoskins ${ }^{37}$, a na zbiory niemieckie - Małgorzaty Gołuszki i Mariana Malickiego ${ }^{38}$, lecz także praca P. Buchwald-Pelcowej poświęcona obecności poloników w bibliotekach hiszpańskich ${ }^{39}$, studium Jacka Puchalskiego odnoszące się

${ }^{31}$ Katalog starych druków biblioteki Poznańskiego Towarzystwa Przyjaciót Nauk. Polonica XVI w. Oprac. Elżbieta Stelmaszczyk, Poznań: PTPN 1991, 194 s.; Wiesław WCZEŚNY, Katalog starych druków Sądeckiej Biblioteki Publicznej w Nowym Sączu: polonica XVI-XVIII w., Nowy Sącz: SBP 2001.

32 Maria ZYCHOWICZOWA, Centralny katalog starych druków Biblioteki Narodowej bez przyszłości?, Roczniki Biblioteczne (53) 2009, s. 187-2003.

33 Edward BARWIŃSKI, Ludwik BIRKENMAJER, Jan ŁOŚ, Sprawozdanie z poszukiwań w Szwecji dokonanych z ramienia Akademii Umiejętności, Kraków: Akademia Umiejętności 1914.

34 Czesław PILICHOWSKI, Nieznane polonica w zbiorach szwedzkich, Gdańsk: Gdańskie Towarzystwo Naukowe 1962.

35 Józef TRYPUĆKO, Polonica vetera Upsaliensia. Catalogue des imprimés polonais ou concernant la Pologne de XVe, XVI ${ }^{e}, X V I I^{e}$ et XVIII siècles conserves à la Bibliothèque de l'Universite Royale d'Uppsala, Uppsala: Universitatis Upsaliensis 1958; idem, The Catalogue of the Book Collection of the Jesuit College in Braniewo held in the University Library in Uppsala. T. 1: Introduction, manuscripts, incunabula. T. 2. 16th and 17th century books. T. 3. Index. Oprac. M. Spandowski. Wydaw. M. Spandowski, S. Szyller, Warszawa-Uppsala: Biblioteka Narodowa, Uppsala Universitetsbibliotek 2007.

36 Zob. m.in. Maciej EDER, ,The Polonica Collection” from Skokloster Castle, Stockholm: Stockholms Universitet 2008; Polonika ze zbiorów zamku Skokloster. Katalog. Oprac. M. Eder przy współpracy Elisabeth Westin Berg, Warszawa: Wydaw. Neriton 2008; M. JUDA, Ewa TEODOROWICZ-HELLMAN przy współpracy Ranghild LUNDGREN, Polonika w Bibliotece katedralnej w Strängnäs/The Polonica in the Library of Strängnäs Cathedra, Sztokholm: Stockholm University 2011.

37 Janina WÓJCICKA-HOSKINS, Early and Rare Polonica of the 15th-17th Centuries in American Libraries. A Bibliographical Survey, Boston: G.K. Hall 1973.

38 Polnische Drucke und Polonica 1501-1700. Katalog der Herzog August Bibliotek Wolfenbüttel. T. 1. 1501-1600, T. 2. 1601-1700. Bearb. von M. Gołuszka und M. Malicki, München 1992 1994.

39 P. BUCHWALD-PELCOWA, Polonica XVI wieku w bibliotekach hiszpańskich, [w:] Z badań nad dawną książka... Cz. 1, Warszawa: Biblioteka Narodowa 1991, s. 97-116. 
do niemieckojęzycznego obszaru językowego ${ }^{40}$ oraz Katalog Jana Linki obejmujący polonika znajdujące się w bibliotece praskich premonstratensów ${ }^{41}$. Pokazują one nie tylko pominięte przez Bibliografie polska wydawnictwa, lecz wskazują także unikatowe egzemplarze zachowane w zbiorach obcych, do których dostęp był tak utrudniony, że niejednokrotnie panowało przekonanie o ich zaczytaniu. Są również wskazówką do dalszych tego rodzaju penetracji, które niewątpliwie należy kontynuować i rozszerzać na coraz to nowe kraje ${ }^{42}$.

Obraz staropolskiego dorobku wydawniczego nie byłby pełny bez uwzględnienia wykazu dawnych czasopism. Rejestracja tego typu wydawnictw prowadzona w Bibliotece Jagiellońskiej, Kórnickiej czy Ossolineum została w znakomity sposób uzupełniona pracami bibliograficznymi Konrada Zawadzkiego ${ }^{43}$.

Przedmiotem zainteresowania są również kalendarze należące do najpopularniejszych wydawnictw doby staropolskiej. Dla badaczy dostępne są ich bibliografie i katalogi, które odnotowują pozycje wydane na ziemiach polskich i poza ich granicami, lecz uwzględniają głównie zasoby bibliotek dysponujących bogatymi tego rodzaju zbiorami ${ }^{44}$.

Staropolskie oficyny typograficzne tłoczyły teksty nie tylko czcionką łacińską, lecz także cyrylicką. Liczne prace dokumentacyjne uwzględniające mniejsze lub większe kolekcje zostały wzbogacone o katalog obejmujący największy w Polsce zbiór druków cyrylickich znajdujących się w Bibliotece Narodowej w Warszawie $^{45}$. Podobnie rzecz się przedstawia, gdy idzie o judaika. Swego rejestratora i badacza znalazły w osobie Krzysztofa Pilarczyka, którego dokonania w dużym

40 Jacek PUCHALSKI, Polonika z obszaru niemieckojęzycznego — poza granicami Rzeczypospolitej - w XVI wieku, Warszawa: Wydaw. SBP 1997.

${ }^{41}$ Polonika czeskie doby renesansu, baroku i oświecenia w bibliotece premonstratensów na Strahowie (Praha). Katalog. Oprac. Jan Linka, Warszawa: Wydaw. Neriton 2011.

${ }^{42}$ Zob. też Piotr TAFIŁOWSKI, Rejestracja rękopiśmiennych i drukowanych poloników w zbiorach obcych, Roczniki Biblioteczne (58) 2014, s. 87-100.

${ }^{43}$ Konrad ZAWADZKI, Gazety ulotne polskie i Polski dotyczace XVI-XVIII wieku. Bibliografia. T. 1. 1514-1661. T. 2. 1662-1728. T. 3. 1501-1725, Wrocław: Zakład Narod. im. Ossolińskich 1977-1984. O korzyściach badawczych, jakie dają druki ulotne, zob. Druki ulotne i okolicznościowe -wartości i funkcje. Materiaty międzynarodowej konferencji naukowej Wojnowice, 8-10 października 2004. Red. nauk. K. Migoń, Marta Skalska-Zlat, A. Żbikowska-Migoń przy współpracy Elżbiety Herden, Wrocław: Wydaw. Uniwersytetu Wrocławskiego 2006.

${ }^{44}$ Zob. m.in.: Kamila KŁODZIŃSKA, Katalog kalendarzy od XVI do XVIII wieku w zbiorach Biblioteki Kórnickiej, Pamiętnik Biblioteki Kórnickiej (8) 1963, s. 176-297; Barbara GÓRSKA, Katalog kalendarzy XVII-XVIII w. w zbiorach Biblioteki Ossolineum, Wrocław: Zakład Narod. im. Ossolińskich 1968; Władysław CHOJNACKI, Wojciech CHOJNACKI, Bibliografia kalendarzy wydanych w języku polskim poza granicami Polski od roku 1716. Mazury, Śląsk Górny i Dolny oraz Ślask Cieszyński, Wrocław: Zakład Narod. im. Ossolińskich 1986; Janina BUŁA, Katalog kalendarzy polskich od XVI do XVIII wieku w zbiorach Biblioteki Czartoryskich, Kraków: Muzeum Narodowe w Krakowie 1994.

45 Katalog druków cyrylickich XV-XVIII wieku w zbiorach Biblioteki Narodowej. Oprac. Zofia Żórawińska, Z. Jaroszewicz-Pieresławcew, Warszawa: Biblioteka Narodowa 2004. 
stopniu wzbogaciły obraz kultury książki adresowanej do społeczności żydowskiej na ziemiach dawnej Rzeczypospolitej ${ }^{46}$.

Badacz podejmujący zagadnienia dziejów ruchu wydawniczego w dobie wczesnonowożytnej dysponuje w miarę pełnym, wymagającym jednak dalszych eksploracji rejestrem dawnych publikacji. Mimo że jest on rozproszony, to jednak wkroczenie nowoczesnych technologii do działań bibliograficzno-katalogowych, systematyczna rozbudowa baz danych i bibliotek cyfrowych ułatwia dostęp i korzystanie z koniecznych do badań źródeł bibliologicznych. Na szczególne podkreślenie zasługuje projekt badawczy realizowany przez Centrum Badawcze Bibliografii Polskiej Estreicherów w Uniwersytecie Jagiellońskim, dzięki któremu nie tylko umożliwiono zdalny dostęp do tego monumentalnego dzieła, lecz także ułatwiono korzystanie z niego, a co niezwykle istotne — na bieżąco rejestrowane są uzupełnienia ${ }^{47}$.

Inaczej sytuacja przedstawia się, gdy idzie o rejestrację dorobku wydawniczego na ziemiach polskich od początku XIX wieku do zakończenia drugiej wojny światowej. Części pierwsza i czwarta pierwszego wydania Bibliografii polskiej, liczące w sumie 11 tomów, opublikowane w latach 1872-1916, nie obejmują istotnej jego części. Podjęta została zatem decyzja o drugim wydaniu pod tytułem Bibliografia polska XIX stulecia, której dotychczas ukazało się 18 tomów $^{48}$. Niedokończona jest także kontynuacja dzieła Estreichera, a więc Bibliografia polska 1901-1939. Obecnie liczy ona 17 tomów ${ }^{49}$. Źródłem informacji jest też „Przewodnik Bibliograficzny”, który ukazywał się pod redakcją Władysława T. Wisłockiego i inne mu podobne spisy poprzedzające Urzędowy Wykaz Druków wydanych w Rzeczypospolitej Polskiej — narodową bibliografię bieżącą. Podejmowane były również działania na rzecz rejestracji produkcji wydawniczej tego okresu w poszczególnych miastach ${ }^{50}$. Po drugiej wojnie światowej produkcję

46 Krzysztof PILARCZYK, Przewodnik po bibliografiach polskich judaików, Kraków: Uniwersytet Jagielloński 1992; Judaika polskie z XVI-XVIII wieku: materiały do bibliografii. Cz. 1. Druki w językach nie-żydowskich. Oprac. K. Pilarczyk, przy współudziale Magdaleny Ruty, Kraków: Księgarnia Akademicka 1995; idem, Leksykon drukarzy ksiąg hebrajskich w Polsce z bibliografia polono-judaików w językach żydowskich (XVI-XVIII wiek), Kraków: Wydaw. Antykwa 2004.

47 Zob. www.estreicher.uj.edu.pl/: Bibliografia staropolska; Bibliografia Polska. Spis Chronologiczny; Bibliografia XIX wieku; Materiały do uzupetnień Bibliografii Estreichera.

48 „Bibliografia polska XIX stulecia”. Wyd. II. T. 1. A-T. 18. Kor-Koskowski, Warszawa: Biblioteka Narodowa 1959-2012.

49 „Bibliografia polska 1901-1939”. T. 1. A-Bars-T. 17. Kn+Korn, Warszawa: Biblioteka Narodowa 1986-2015. Zob. też www.bn.org.pl/katalogi-i-bibliografie/bibliografia-narodowa/ bibliografia-polska-1901-1939.

50 Zob. m.in. Maria MARCZYŃSKA, Ryszard ŻMUDA, Bibliografia tódzkiej produkcji wydawniczej: 1918-1939, Łódź: Uniwersytet Łódzki 1986. 
wydawniczą dokumentuje „Przewodnik Bibliograficzny”51. Sytuacja polityczna w Polsce Ludowej i działania władz w zakresie cenzury miały wpływ na pojawienie się tak zwanego drugiego obiegu wydawniczego. Rejestrację wydawnictw niezależnych podjęto najpierw na obczyźnie, a po zmianach ustrojowych w 1989 roku kontynuowano je w kraju ${ }^{52}$.

Wymiernym efektem wieloletnich niekiedy prac zespołowych są wydawnictwa informacyjne, w których ważne miejsce zajmuje problematyka odnosząca się do dziejów ruchu wydawniczego. Nie sposób nie przytoczyć Encyklopedii wiedzy o ksiażce oraz Słownika pracowników ksiażki polskiej ${ }^{53}$. I chociaż przekazują one stan wiedzy w momencie opracowania, to jednak są niezwykle ważnym i pożytecznym źródłem informacji. Środowisko badawcze z wielkim zainteresowaniem oczekuje na będącą w przygotowaniu Encyklopedię książki, która zastąpi swoją wielce wysłużoną poprzedniczkę. Zapowiadany jest też kolejny suplement Słownika. Nie można pominąć też Polskiego słownika biograficznego zawierającego biogramy nie tylko znaczniejszych, lecz także średniej miary drukarzy i wydawców, które oparte są na starannej kwerendzie archiwalnej oraz bibliotecznej i dostarczają użytkownikowi informacji, które niejednokrotnie trudno znaleźć w powyższych informatorach. Podobną rolę odgrywają słowniki biograficzne poszczególnych ziem czy miast, jak chociażby Słownik biograficzny Warmii, Prus Ksiażęcych i Ziemi Malborskiej od połowy XV do końca XVIII wieku (Olsztyn 1984), Wielkopolski stownik biograficzny (Warszawa 1981), Ślaski słownik biograficzny (t. 1-3, Katowice 1977-1981 i seria nowa t. 1, Katowice 1999) czy Stownik biograficzny miasta Lublina (t. 1-4, Lublin 1993-2014). Należy również wspomnieć o Literaturze polskiej. Przewodniku encyklopedycznym (t. 1-2, Warszawa 1984) oraz Encyklopedii katolickiej (t. 1-20, Lublin 1995-2014).

Połowa lat 70. ubiegłego stulecia to rozwój kształcenia akademickiego w zakresie nauki o książce, bibliotece i informacji. Niewątpliwie w związku z potrzebami dydaktycznymi pojawiły się próby syntez dziejów książki drukowanej

${ }^{51}$ Zob. Józef KORPAŁA, Krótka historia bibliografii polskiej, Wrocław: Ossolineum 1986, s. $165-168,211-216$.

52 Zob. m.in. Bibliografia publikacji podziemnych w Polsce. T. 1. 13 XII 1981-VI 1986. Oprac. Józefa Kamińska, Paryż: Editions Spotkania 1988; T. 2. 1 I 1986-31 XII 1987. Oprac. Wojciech CHOJNACKI, Marek JASTRZĘBSKI, Warszawa: Editions Spotkania [1993]; Bibliografia niezależnych wydawnictw ciagtych z lat 1976-1990, Warszawa: Biblioteka Narodowa 2001; Łukasz JASTRZĄB, Poza cenzurą. Wydawnictwa i materiaty niezależne z lat 1976-1989 w zbiorach Biblioteki Kórnickiej, Kórnik: Polska Akademia Nauk Biblioteka Kórnicka 2013.

53 Encyklopedia wiedzy o książce. Pod red. Aleksandra Birkenmajera et al., Wrocław: Zakład Narod. im. Ossolińskich 1971, 2874 szp.; Słownik pracowników książki polskiej. T. 1 - Suplement. Pod red. Ireny Treichel; Suplement 2-3. Pod red. Hanny Tadeusiewicz, Warszawa: PWN; Wydaw. SBP 1972-2010. 
Heleny Szwejkowskiej ${ }^{54}$. Funkcja pomocy dydaktycznych przypadła też kolejnym tego rodzaju dziełom Kazimiery Maleczyńskiej i A. Żbikowskiej-Migoń, które jednak mniej uwagi poświęciły dziejom drukarstwa i ruchu wydawniczego, bardziej koncentrując się na innych obszarach życia książki ${ }^{55}$. Ważną rolę w tym zakresie odgrywają również prace Barbary Bieńkowskiej i Haliny Chamerskiej ${ }^{56}$. Studia P. Buchwald-Pelcowej i Krystyny Bednarskiej-Ruszajowej, chociaż nie mają charakteru podręcznika czy skryptu, mogą być pewnym ich uzupełnieniem $^{57}$. Podobną funkcję pełni też Polskie drukarstwo J. Sowińskiego ${ }^{58}$. Te ważne i potrzebne wydawnictwa niestety nie oddają już w pełni aktualnego stanu wiedzy. Niewątpliwie istnieje potrzeba przygotowania podręcznika do dziejów książki drukowanej w Polsce, który służyłby nie tylko studentom studiującym na kierunkach w zakresie bibliologii i informatologii, lecz także w obszarach nauk pokrewnych tej dyscyplinie.

Problemem, wokół którego toczyła się ożywiona dyskusja, było zagadnienie początków sztuki drukarskiej na ziemiach polskich. Zaprezentowała ją i krytycznie odniosła się do dotychczasowych ustaleń w 1975 roku A. Kawecka-Gryczowa ${ }^{59}$. Dyskusja ta dotyczyła nie tylko lokalizacji pierwszej oficyny i jej wytworów, lecz także osoby drukarza. Niemal wszyscy badacze za kolebkę polskiego drukarstwa uznali Kraków, a swoistym podsumowaniem badań nad pierwszym typografem w osobie Kaspra Straubego (jednak ze znakiem zapytania) jest poświęcony temu pionierowi sztuki drukarskiej w Polsce artykuł zamieszczony w pierwszym tomie Drukarzy dawnej Polski ${ }^{60}$. Inną koncepcję przedstawiła Eliza Szandorowska, któ-

${ }^{4}$ Helena SZWEJKOWSKA, Książka drukowana XV-XVIII wieku. Zarys historyczny. Wyd. 1-5, Warszawa: PWN 1961-1987; eadem, Wybrane zagadnienia z dziejów książki XIX-XX wieku. Wyd. 1-4, Warszawa: PWN 1972-1981.

55 Kazimiera MALECZYŃSKA, Historia ksiązki i jej funkcji społecznej, Wrocław: Wydaw. Uniwersytetu Wrocławskiego 1987; A. ŻBIKOWSKA-MIGOŃ, Dzieje książki i jej funkcji społecznej: wiek XVIII, Wrocław: Wydaw. Uniwersytetu Wrocławskiego 1987.

56 Barbara BIEŃKOWSKA, Halina CHAMERSKA, Zarys dziejów książki, Warszawa: Wydaw. Spółdzielcze 1987; eadem, Tysiąc lat ksiązki i bibliotek w Polsce, Wrocław: Zakład Narod. im. Ossolińskich 1992; B. BIEŃKOWSKA przy współpracy Elżbiety Maruszak, Książka na przestrzeni dziejów, Warszawa: Wydaw. Centrum Edukacji Bibliotekarskiej, Informacyjnej i Dokumentacyjnej 2005.

57 P. BUCHWALD-PELCOWA, „Drukowi winniśmy oświecenie naszego wieku...” Rola książki w drodze ku Oświeceniu, Warszawa: Uniwersytet Warszawski 2003; Krystyna BEDNARSKA-RUSZAJOWA, Uczyć - bawić - wychowywać. Ksiażka i jej funkcja społeczna w Polsce w okresie Oświecenia, Kraków: Oficyna Wydawnicza „Impuls” 2004.

58 Janusz SOWIŃSKI, Polskie drukarstwo. Historia drukowania typograficznego i sztuki typograficznej w Polsce w latach 1473-1939. Wyd. 1-2, Wrocław: Zakład Narod. im. Ossolińskich 1988; Wrocław: Tart 1996.

59 A. KAWECKA-GRYCZOWA, Dzieje drukarstwa..., s. 17-22.

60 Drukarze dawnej Polski od XV do XVIII wieku. T. 1. Małopolska, cz. 1. Wiek XV-XVI. Praca zbiorowa pod red. A. Kaweckiej-Gryczowej, Wrocław: Zakład Narod. im. Ossolińskich 1983, s. 217-225. 
ra za najwcześniejszą lub jednoczesną krakowskiej drukarnię uznała oficynę Typografa Kazań papieża Leona I, zlokalizowaną najprawdopodobniej w Chełmnie, a prowadzoną przez przybyłych tam z Niderlandów Braci Wspólnego Życia. Mimo krytycznego stosunku do tej hipotezy Anny Lewickiej-Kamińskiej, wskazującej raczej na Wrocław, E. Szandorowska pozostała przy swoim zdaniu i przytoczyła kolejne, przemawiające za jej stanowiskiem argumenty ${ }^{61}$. Dopóki jednak nie pojawią się nowe źródła dotyczące tego problemu, będzie on budził wątpliwości i rodził być może kolejne hipotezy.

Początki i osiągnięcia piętnastowiecznego drukarstwa na Śląsku w wyczerpujący sposób zaprezentowali w swoich studiach Bronisław Kocowski i Marta Burbianka ${ }^{62}$, drukarniom położonym zaś na Pomorzu wiele uwagi poświęcił Zbigniew Nowak. Efekty swoich badań zaprezentował najpierw w pogłębionym studium na temat pierwocin sztuki typograficznej na tym obszarze, a po wielu latach powtórzył i poszerzył je w zbiorze poświęconym dziejom kultury książki w Prusach Królewskich ${ }^{63}$.

Zainteresowanie zarówno badaczy polskich, jak i obcych budzą też początki drukarstwa cyrylickiego w Krakowie. Analizę dokonań w tym zakresie badaczy polskich i radzieckich przeprowadzoną przez A. Kawecką-Gryczową uzupełnia studium Szczepana Karola Zimmera oraz jego krytyczne omówienie pióra Jana Pirożyńskiego ${ }^{64}$.

Dzieje drukarstwa to w znacznej mierze historia oficyn typograficznych. Niewątpliwie do ważniejszych osiągnięć w tym zakresie należą Drukarze dawnej Polski $^{65}$. Intencją pomysłodawczyni projektu — A. Kaweckiej-Gryczowej — było

${ }^{61}$ E. SZANDOROWSKA, Jeszcze raz w sprawie „Drukarza kazań papieża Leona I” (Hain 10015), [w:] Z badań nad dawna... Cz. 1, s. 37-52.

62 Bronisław KOCOWSKI, Ślaskie studia inkunabulistyczne, [w:] B. KOCOWSKI, Karol GŁOMBIOWSKI, Marta BURBIANKA, Z dziejów książki na Śląsku, Wrocław 1953, s. 5-27; M. BURBIANKA, Badania nad warsztatem Kaspra Elyana, Roczniki Biblioteczne (16) 1972, s. $39-48$.

63 Zbigniew NOWAK, Początki sztuki drukarskiej na Pomorzu w XV wieku, Gdańsk: PAN, Biblioteka Gdańska 1976; idem, Po starą księgę sięgam. Szkice z dziejów kultury książki w Prusach Królewskich od XV do XVIII wieku, Gdańsk: słowo/obraz terytoria 2008.

${ }^{64}$ Szczepan Karol ZIMMER, The beginning of Cyrillic printing Cracow, 1491: from the orthodox past in Poland. Red. Ludwik Krzyżanowski, Irene Nagurski, współpraca Krystyna M. O1szer, New York: Polish Institute of Arts and Science of America 1983; J. PIROŻYŃSKI, Jeszcze raz o Szwajpolcie Fiolu. Uwagi na marginesie pracy Szczepana K. Zimmera, Roczniki Biblioteczne (29) 1985 [druk 1987] z. 1/2 s. 3-21.

${ }^{65}$ Drukarze dawnej... T. 1, cz. 1; cz. 2. Wiek XVII-XVIII. vol. 1. A-K. vol. 2. $L-\dot{Z}$ i drukarnie żydowskie. Praca zbiorowa pod red. J. Pirożyńskiego, Kraków: PAU 2000. T. 3, cz. 1. Wielkopolska. Oprac. A. Kawecka-Gryczowa, Krystyna Korotajowa, Jan Sójka, Wrocław: Zakład Narod. im. Ossolińskich 1977; cz. 2: Mazowsze z Podlasiem. Oprac. K. Korotajowa et al. pod red. K. Korotajowej i J. Krauze-Karpińskiej, Warszawa: Wydaw. IBL PAN 2001. T. 4. Pomorze. Oprac. A. Kawecka-Gryczowa, K. Korotajowa, Wrocław: Zakład Narod. im. Ossolińskich 1962; Z. 5: Wielkie Księstwo Litewskie. Oprac. A. Kawecka-Gryczowa, Wrocław: Zakład Narod. im. Osso- 
przedstawić „,W miarę możliwości rodzaj piśmiennictwa przepływającego przez prasy, krąg autorski, zależność czy samodzielność nakładczą właściciela tłoczni, a nawet — w dalekiej perspektywie — odbiorców wyprodukowanych książek"66. Projekt wydaje się zamknięty, mimo iż brakuje tomu drugiego, który miał obejmować oficyny działające na terenie Śląska. Biorąc jednak pod uwagę, że ziemie te pozostawały poza granicami państwa polskiego, taki tok rozumowania jest jak najbardziej zasadny. Niemniej jednak, ze względu na kontakty i wzajemne oddziaływanie książki, jej ludzi i instytucji tych sąsiadujących z sobą obszarów, warto byłoby podjąć zadanie opracowania tomu zbliżonego charakterem do tej serii, tym bardziej że stosunkowo dobrze rozpoznana jest obecność polskiej książki na Śląsku. Pewnym podsumowaniem osiągnięć w tym zakresie do połowy lat 70. ubiegłego stulecia jest zbiór studiów będących pokłosiem konferencji naukowej zorganizowanej z okazji 500. rocznicy polskiego słowa drukowanego na tym obszarze $^{67}$. Odnotować należy również monograficzne opracowanie tego zagadnienia oraz wiele prac poświęconych sztuce drukarskiej w konkretnych miejscowościach lub też poszczególnym oficynom ${ }^{68}$.

Warsztaty drukarskie funkcjonujące na ziemiach dawnej Rzeczypospolitej mają stosunkowo bogatą historiografię. Niektóre ośrodki doczekały się odrębnych opracowań $^{69}$, jednak w zdecydowanej większości odnoszą się one do przedstawienia czy to całości, czy tylko pewnych aspektów działalności typograficznej poszczególnych oficyn. Niewątpliwie wiele z nich wymaga pogłębionego monograficznego opracowania, a swoistym punktem odniesienia mogą być prace Janiny Dobrzynieckiej i Józefa Szczepańca dotyczące drukarni Uniwersytetu Jagiellońskiego oraz warszawskiej Drukarni Wolnej Jana Potockiego ${ }^{70}$. Ostatnia z wymienionych zwraca szczególną uwagę, gdyż zawiera nie tylko obraz działalności oficyny, lecz także bibliografię jej publikacji, dokumentację dotyczącą wyposa-

lińskich 1959. Z. 6. Małopolska-Ziemie Ruskie. Oprac. A. Kawecka-Gryczowa, K. Korotajowa, Wojciech Krajewski, Wrocław: Zakład Narod. im. Ossolińskich 1960.

66 A. KAWECKA-GRYCZOWA, Stowo wstepne, [w:] ibidem. T. 4, s. VII.

67 500-lecie polskiego stowa drukowanego na Ślasku. Materiały sesji naukowej 9-11 X1975, Wrocław, Wrocław: Wydaw. Uniwersytetu Wrocławskiego 1978.

68 Zob. m.in.: M. BURBIANKA, Z dziejów drukarstwa śląskiego w XVII wieku. Baumannowie, Wrocław: Zakład Narod. im. Ossolińskich 1977; Aleksandra MENDYKOWA, Kornowie, Wrocław: Ossolineum 1980; eadem, Dzieje książki polskiej na Śląsku, Wrocław: Ossolineum 1991; A. ŻBIKOWSKA-MIGOŃ, Drukarstwo i ruch wydawniczy w Bolesławcu w okresie oświecenia (1750-1820), Roczniki Biblioteczne (34) 1990, z. 1/2, s. 63-99.

69 Zob. m. in. Alojzy TUJAKOWSKI, Z dziejów drukarstwa i piśmiennictwa na Pomorzu. 400 lat drukarstwa $w$ Toruniu 1569-1969, Warszawa: Ludowa Spółdzielnia Wydawnicza 1970; Wiktor FRANTZ, W gnieździe drukarstwa polskiego, Kraków: Wydaw. Literackie 1974.

70 Janina DOBRZYNIECKA, Drukarnie Uniwersytetu Jagiellońskiego 1674-1783, Warszawa: PWN 1975; Józef SZCZEPANIEC, Drukarnia Wolna Jana Potockiego w Warszawie 1788 1792, Wrocław: Wydaw. Uniwersytetu Wrocławskiego 1998. 
żenia technicznego, wykorzystane gatunki papieru wraz z filigranami oraz aneks źródłowy.

Upadek państwa polskiego pod koniec XVIII wieku, a w związku z tym pojawienie się zupełnie nowych warunków politycznych, społecznych i kulturalnych dla działalności wydawniczej, stanowionych przez państwa zaborcze, zmieniły oblicze tej sfery wytwórczości. Istotny wpływ miały też nowe wynalazki w znakomity sposób usprawniające procesy publikacyjne. Zjawiska te jeszcze bardziej pogłębiły się po uzyskaniu niepodległości i w wyniku zmian ustrojowych po zakończeniu drugiej wojny światowej. Ogólne tendencje w zakresie ruchu wydawniczego w różnych przedziałach czasowych przedstawili - między innymi — K. Maleczyńska, Henryk Hollender, Janusz Kostecki, Witold Adamiec i Janet Zamroczek $^{71}$. Elżbieta Słodkowska skoncentrowała się na określeniu i zbadaniu warunków do produkcji i dystrybucji wydawnictw w Królestwie Polskim między rokiem 1815 a $1830^{72}$. Przeobrażeniom rynku wydawniczego w Warszawie doby zaborów i ukształtowaniu się wydawców jako nowej grupy zawodowej i społecznej poświęciła uwagę Marianna Mlekicka ${ }^{73}$. Pojawiły się również studia nad zmianami organizacyjnymi i technicznymi w zakładach poligraficznych ${ }^{74}$.

Dzięki publikacjom Artura Jazdona stosunkowo dobrze rozpoznane i zbadane są różnorakie zjawiska związane z ruchem wydawniczym w dobie zaborów w Wielkim Księstwie Poznańskim i w samym Poznaniu ${ }^{75}$. Różne aspekty dziejów książki i ruchu wydawniczego na Śląsku pod panowaniem pruskim podjęła w swoich pracach Elżbieta Gondek ${ }^{76}$. Liczne grono badaczy ma problematyka

71 K. MALECZYŃSKA, Polski repertuar wydawniczy doby zaborów (Problematyka badawcza i główne tendencje rozwojowe), Roczniki Biblioteczne (27) 1983 [druk 1985] z. 1/2, s. 273 288; eadem, Książki i biblioteki w Polsce okresu zaborów, Wrocław: Ossolineum 1987, s. 9-61; Henryk HOLLENDER, Produkcja wydawnicza Królestwa Polskiego na poczatku XX wieku, [w:] Instytucje - publiczność - sytuacje lektury: studia z historii czytelnictwa. T. 3. Pod red. Janusza Kosteckiego, Warszawa: Biblioteka Narodowa 1991, s. 181-211; J. KOSTECKI, Ruch wydawniczy na ziemiach polskich (1877-1986), ibidem. T. 4, Warszawa: Biblioteka Narodowa 1992, s. 153-224; Witold ADAMIEC, O dostępności książki w latach siedemdziesiątych, Rocznik Biblioteki Narodowej (17/18) 1981/1982 [druk 1986], s. 133-156; Janet ZAMROCZEK, Ruch wydawniczy w Polsce po r. 1945, Zeszyty Historyczne (100) 1992, s. 209-231.

72 Elżbieta SŁODKOWSKA, Produkcja i rozprowadzanie wydawnictw w Królestwie Polskim w latach 1815-1830, Warszawa: Biblioteka Narodowa 2003.

${ }_{73}$ Marianna MLEKICKA, Wydawcy ksiązek w Warszawie w okresie zaborów, Warszawa: PWN 1987.

74 Stefan LEWANDOWSKI, Poligrafia warszawska 1870-1914, Warszawa: Książka i Wiedza 1982.

75 Artur JAZDON, Polski ruch wydawniczy w Wielkim Księstwie Poznańskim w latach 1831-1862, Warszawa: PWN 1990; idem, Wydawcy poznańscy 1815-1914: ksztaltowanie środowiska i repertuaru wydawniczego, Poznań: Wydaw. Naukowe UAM 2012.

${ }_{76}$ Elżbieta GONDEK, Polska książka literacka na Ślasku pod panowaniem pruskim 1795 1863, Katowice: Wydaw. Uniwersytetu Śląskiego 1995; eadem, Rynek ksiązki na Śląsku pod panowaniem pruskim w XIX w., Katowice: Uniwersytet Śląski 2001. 
odnosząca się do zaboru austriackiego. W swoich pracach kierują oni uwagę nie tylko na kształtowanie repertuaru wydawniczego i udziału w tym autorów-nakładców, lecz także na techniczne aspekty działalności drukarskiej ${ }^{77}$.

Obraz polskiego ruchu wydawniczego nie byłby pełny bez uwzględnienia działalności drukarzy i wydawców na obczyźnie. Tej problematyce wiele studiów poświęcił Andrzej Kłossowski ${ }^{78}$. Do tych badań włączyła się również Hanna Batorowska i Jacek Kuszłejko ${ }^{79}$.

Uwagę badaczy zwracały też kwestie odnoszące się do drukarstwa cyrylickiego. Zajęto się nie tylko rejestracją druków tłoczonych czcionką cyrylicką, lecz podjęto też bardziej pogłębione studia dotyczące książki adresowanej do prawosławnego czy unickiego odbiorcy. Na szczególną uwagę zasługują badania Marii Błońskiej ${ }^{80}$ oraz Z. Jaroszewicz-Pieresławcew, która skupiła uwagę na dorobku typograficznym oficyn pracujących na terytorium Wielkiego Księstwa Litewskie$\mathrm{go}^{81}$. Istotne uzupełnienia w stosunku do treści artykułów poświęconych drukarniom pracującym na rzecz ruskiej społeczności, widniejącym w zeszy tach piątym i szóstym Drukarzy dawnej Polski, znajdujemy w zbiorze studiów poświęconych prawosławnym oficynom wydawniczym ${ }^{82}$. Badania nad drukarstwem greckim zawdzięczamy Janinie Czerniatowicz ${ }^{83}$.

77 M.in. Maria KOCÓJOWA, Krakowski świat książki doby autonomii galicyjskiej (kształtowanie nowego modelu w latach 1867-1882), Kraków: Uniwersytet Jagielloński 1990; Anna ALEKSIEWICZ, Drukarstwo w Rzeczypospolitej Krakowskiej i Galicji Zachodniej w latach 1815-1860, Wrocław: Państwowe Wydawnictwo Naukowe 1976; eadem, Historia drukarstwa Galicji Wschodniej w latach 1815-1860, Wrocław: Wydaw. Uniwersytetu Wrocławskiego 1992; Anna GRUCA, Nakładem własnym...: autorzy jako wydawcy swoich prac w Krakowie w dobie autonomii galicyjskiej, Kraków: Wydaw. Uniwersytetu Jagiellońskiego 2007.

78 M.in. Andrzej KŁOSSOWSKI, Polskie ośrodki wydawnicze na obczyźnie. Rys historyczny, [w:] Polska literatura emigracyjna. Materiaty z sesji naukowej (10 czerwca 1981 r.), Lublin: Polonijne Centrum Kulturalno-Oświatowe UMCS 1983, s. 33-53; idem, Na obczyźnie. Ludzie polskiej książi, Wrocław: Ossolineum 1984.

79 Hanna BATOROWSKA, Jan Nepomucen Bobrowicz polski wydawca i ksieggarz w Saksonii w czasach Wielkiej Emigracji, Kraków: Wydaw. Naukowe WSP 1992; Jacek KUSZŁEJKO, Ksiązka polska w Rosji na przełomie XIX i XX wieku, Warszawa: Biblioteka Narodowa 1993.

80 M.in. Maria BŁOŃSKA, Polonica cyrylickie XV-XVIII wieku, czyli o drukach cyrylickich wydawanych $w$ państwie polsko-litewskim. Uwagi wstępne, [w:] Z badań nad dawna książka... Cz. 2, s. 433-554.

81 Z. JAROSZEWICZ-PIERESŁAWCEW, Druki cyrylickie z oficyn Wielkiego Księstwa Litewskiego w XVI-XVIII wieku, Olsztyn: Wydaw. Uniwersytetu Warmińsko-Mazurskiego 2003.

82 Prawostawne oficyny wydawnicze w Rzeczypospolitej. Pod red. Antoniego Mironowicza, Urszuli Pawluczuk i Piotra Chomika, Białystok: Instytut Historii Uniwersytetu w Białymstoku 2004.

83 Janina CZERNIATOWICZ, Rola drukarstwa greckiego w rozwoju piśmiennictwa naukowego w Polsce do połowy XVII wieku. Kraków, Zamość, [w:] Z dziejów polskiej kultury umystowej w XVI i XVII w. Pod red. Waldemara Voisé, Wrocław: Zakład Narod. im. Ossolińskich 1976, s. 157-225; eadem, Początki grecysystyki a rozwój drukarstwa greckiego na Śląsku do połowy XVII w., [w:] 500-lecie polskiego..., s. 57-73. 
Bardziej dogodne niż w wielu innych krajach warunki do prowadzenia działalności typograficznej na ziemiach polskich znalazła społeczność żydowska. Liczne, mniej lub bardziej wydajne, warsztaty tłoczyły druki w języku hebrajskim i językach żydowskich. Wcześniejsze osiągnięcia w historiografii drukarstwa żydowskiego wykorzystane zostały w kolejnych tomach Drukarzy dawnej Polski. Jednak teksty im poświecone, zamieszczone w częściach opublikowanych na przełomie lat 50. i 60. ubiegłego stulecia, nie odpowiadają już aktualnemu stanowi badań. Ich braki zostały uzupełnione dzięki badaniom Krzysztofa Pilarczyka, który nie tylko wydatnie zwiększył rejestr tych druków, lecz także zwrócił uwagę na ich przeznaczenie ${ }^{84}$. Do rozwiązania pozostaje wiele pytań badawczych dotyczących tego zjawiska w XIX i XX wieku. Całości problematyki nie wyczerpują badania cząstkowe odnoszące się do pewnych obszarów czy miejscowości, a nawet poszczególnych warsztatów ${ }^{85}$. Podjęto też — nieliczne jednak — działania na rzecz rejestracji druków żydowskich w zasobach bibliotecznych ${ }^{86}$.

Stosunkowo dobrze rozpoznane i zbadane są problemy dotyczące dziejów drukarstwa muzycznego, zwłaszcza w odniesieniu do okresu wczesnonowożytnego. Największe osiągnięcia w tym zakresie przypisać należy Marii Przyweckiej-Sameckiej. W swoich badaniach koncentrowała się nie tylko na dokonaniach w tym zakresie polskich warsztatów typograficznych, lecz także europejskich ${ }^{87}$. Zjawiskom zachodzącym w europejskiej kulturze muzycznej szesnastego stulecia w kontekście wynalazku typografii przez Jana Gutenberga poświęcił pogłębione studium Paweł Gancarczyk ${ }^{88}$.

${ }^{84}$ K. PILARCZYK, Talmud i jego drukarze w Pierwszej Rzeczypospolitej, Kraków: PAU 1998; idem, Leksykon drukarzy...

85 Zob. m.in. K. MIGOŃ, Drukarstwo orientalne i hebrajskie na Śląsku w XVI-XVIII w., [w:] 500-lecie polskiego..., s. 75-81; Marta MEDUCKA, Drukarstwo żydowskie w województwie kieleckim (1918-1939), Folia Bibliologica (40/41) 1992/1993, s. 55-67; Konrad ZIELIŃSKI, Drukarnie, księgarnie, biblioteki i czytelnie żydowskie w Lublinie do 1918 r. (Przyczynek do dziejów świeckiego życia kulturalnego Żydów lubelskich), [w:] Lublin a ksiązka. Red Antoni Krawczyk, Elżbieta Józefowicz-Wisińska, Lublin: Lubelskie Towarzystwo Naukowe 2004, s. 509-522.

86 Monika ADAMCZYK-GARBOWSKA, Judaica w zbiorach UMCS, [w:] Lublin a książka..., s. 431-440; Barbara ŁĘTOCHA, Aleksander MESSER, Alina CAŁA, Netzem SHLOMO, Żydowskie druki ulotne w II Rzeczypospolitej w zbiorach Biblioteki Narodowej, Warszawa: Biblioteka Narodowa 2004.

87 Maria PRZYWECKA-SAMECKA, Poczatki drukarstwa muzycznego w Niemczech i Szwajcarii, Roczniki Biblioteczne (21) 1977 z. 1/2, s. 91-116; eadem, Z dziejów węgierskiego drukarstwa muzycznego (XVI-XVIII w.), Roczniki Biblioteczne (29) 1985 z. 1/2, s. 115-129; eadem, Drukarstwo muzyczne w Europie do końca XVIII wieku, Wrocław: Ossolineum 1987; eadem, Rozwój drukarstwa muzycznego w Niderlandach (XVI-XVIII w.), Wrocław: Wydaw. Uniwersytetu Wrocławskiego 1989; eadem, Dzieje drukarstwa muzycznego w Polsce do końca XVIII wieku, Wrocław: Wydaw. Uniwersytetu Wrocławskiego 1993.

88 Paweł GANCARCZYK, Muzyka wobec rewolucji druku. Przemiany w kulturze muzycznej XVI wieku, Toruń: Wydaw. Naukowe UMK 2011. 
Równie korzystnie przedstawia się sytuacja, gdy idzie o muzyczny ruch wydawniczy w Królestwie Polskim do upadku powstania styczniowego. Badaczem zgłębiającym te zagadnienia jest Wojciech Tomaszewski. Jego badania nad dziejami warszawskiego edytorstwa muzycznego od ostatniej ćwierci XVIII stulecia po rok 1865 uwieńczone zostały wieloma artykułami oraz opracowaniem monograficznym, w którym przedstawił nie tylko produkcję druków muzycznych, lecz także zagadnienia związane z ich dystrybucją. W obszarze jego zainteresowań znalazła się tego rodzaju działalność realizowana poza miastem stołecznym. Dokonał rejestracji polskich druków muzycznych pierwszej połowy XIX wieku ${ }^{89}$.

Badaniami obejmowano też zjawiska kształtujące strukturę i charakter produkcji wydawniczej, a związane z uwarunkowaniami natury politycznej, społecznej, wyznaniowej, a nawet gospodarczej. Jednym z nich jest cenzura, której zasięg i stopień restrykcyjności był wynikiem działań władz państwowych i kościelnych różnych religii i wyznań. Zjawisko to w dobie staropolskiej znalazło swojego badacza przede wszystkim w osobie P. Buchwald-Pelcowej. Jej erudycyjne, oparte na szerokiej podstawie źródłowej i literaturze przedmiotu studia w zasadzie wyczerpują problematykę badawczą ${ }^{90}$. W zagadnienia kontroli, prawa do publikacji określonych wydawnictw i zabezpieczania optymalnych warunków do działalności typograficznej wpisują się dokonania poświęcone przywilejom drukarskim ${ }^{91}$.

Systemy prawne państw zaborczych, obowiązujące na ziemiach polskich po upadku I Rzeczypospolitej w radykalny sposób zmieniły sytuację instytucji wydawniczych. Każde z nich stosowało różne formy działań cenzorskich, zróżnicowany był też stopień ich nasilenia. Obraz funkcjonowania władz pruskich w tym zakresie na terytorium Wielkopolski znajdujemy w studium Grzegorza Kucharczyka, który kieruje uwagę zarówno na międzynarodowy aspekt tego zjawiska, jak i na cenzurę wobec polskich aspiracji niepodległościowych oraz polskich symboli, a także kwestii wyznaniowych i publikacji antyjudaistycznych $\mathrm{i}$ antysemickich ${ }^{92}$.

89 Wojciech TOMASZEWSKI, Warszawskie edytorstwo muzyczne w latach 1772-1865, Warszawa: Biblioteka Narodowa 1992; idem, Edytorstwo i księgarstwo muzyczne na prowincji Królestwa Polskiego w latach 1815-1862, [w:] Biblioteka muzyczna 1996-1999. Pod red. Andrzeja Spóza, Elżbiety Wojnowskiej, Stanisława Hrabaja, Warszawa: SBP 2004, s. 9-24; idem, Bibliografia druków muzycznych 1800-1850, Warszawa: Biblioteka Narodowa 1992. Por. też Janina MENDYSOWA, Katalog druków muzycznych XVI, XVII i XVIII w. w Bibliotece Uniwersytetu Warszawskiego. T. 1. Wiek XVI, Warszawa: Wydaw. Uniwersytetu Warszawskiego 1970.

90 P. BUCHWALD-PELCOWA, Cenzura $w$ dawnej Polsce. Między prasq drukarska a stosem, Warszawa: Wydaw. SBP 1997. Zob. też inne jej artykuły na ten temat opublikowane w: Historia literatury i historia książki. Studia nad książka i literatura od średniowiecza po wiek XVIII, Kraków: Universitas 2005.

${ }_{91}$ M. JUDA, Przywileje drukarskie w Polsce, Lublin: Agencja Wydawniczo-Handlowa AD 1992.

92 Grzegorz KUCHARCZYK, Cenzura pruska w Wielkopolsce w czasach zaborów 1815 1914, Poznań: Wydaw. Poznańskie 2001. Zob. też Bronisława WOŹNICZKA-PARUZEL, Pruska 
W odniesieniu do zaboru rosyjskiego liczne studia poświęcone tym zagadnieniom poświęcił Janusz Kostecki. Jego badania skoncentrowały się na problemach związanych z importem i obiegiem polskojęzycznych publikacji na wskazanym obszarze między rokiem 1865 a 1904. Oprócz opracowań ich efektem były także edycje źródłowe, szczególnie w odniesieniu do prasy. Działaniom cenzorskim władz carskich poświęcił też swoje eksploracje badawcze Henryk Bałabuch ${ }^{93}$.

Sytuację w tym zakresie na terenie zaboru austriackiego poznajemy dzięki studiom Anny Aleksiewicz, która badaniami objęła przede wszystkim Lwów ${ }^{94}$. Nie pominęła tej problematyki również w monograficznych opracowaniach dotyczących dziejów galicyjskiego drukarstwa ${ }^{95}$. Zagadnień tych dotykają autorzy bardziej ogólnych opracowań poświęconych kulturze książki na tym obszarze ${ }^{96}$.

Zmiany społeczno-polityczne w Polsce po drugiej wojnie światowej doprowadziły do znaczących ograniczeń w zakresie wolności słowa. O kierunkach i zakresie ingerencji władz państwowych w obraz rynku wydawniczego w okresie tworzenia podstaw nowego ustroju dowiadujemy się z badań Stanisława Adama Kondka ${ }^{97}$. O korzyściach naukowych płynących z wykorzystania sprawozdań Głównego Urzędu Kontroli Prasy, Publikacji i Widowisk świadczy opracowanie

cenzura wobec problematyki politycznej i społecznej w polskim piśmiennictwie Prus Zachodnich 1848-1914, [w:] Studia z dziejów polskiej myśli politycznej. T. 5. Dążenia do niepodległości Polski a ocena rządów zaborczych w XIX wieku. Pod red. Sławomira Kalembki, Toruń: Wydaw. UMK 1992, s. $157-185$.

93 Granice wolności stowa w zaborze rosyjskim w latach 1865-1904. Wykaz publikacji polskojęzycznych zakwestionowanych oraz dopuszczonych do obiegu przez carska cenzure zagraniczna. Oprac. J. Kostecki, Małgorzata Rowicka. T. 1-3, Warszawa: Biblioteka Narodowa 2006; J. KOSTECKI, Trudny proces przenikania. Carska cenzura zagraniczna wobec importu publikacji w języku polskim w latach 1865-1904, Warszawa: Biblioteka Narodowa 2011; Prasa Królestwa Polskiego w opinii władz cenzury rosyjskiej: dokumenty. Wstęp, oprac. i przekład Janusz Kostecki, Michał Tobera. Warszawa: Biblioteka Narodowa 2013; H. BAŁABUCH, Nie tylko cenzura: prasa prowincjonalna Królestwa Polskiego w rosyjskim systemie prasowym w latach 1865-1915, Lublin: Wydaw. UMCS 2001.

94 M.in. A. ALEKSIEWICZ, Działalność cenzury austriackiej we Lwowie w pierwszej potowie XIX w., Acta Universitatis Wratislaviensis No 2290 Bibliotekoznawstwo 23, Wrocław 2000, s. 7-36; eadem, Spór Karola Cieszewskiego, redaktora pisma „Czytelnia dla Młodzieży”, z Dyrekcja Policji we Lwowie w świetle zachowanej korespondencji, Roczniki Biblioteczne (49) 2005, s. 277-285; eadem, Z badań nad cenzura we Lwowie w XIX wieku, [w:] Kraków-Lwów: książki, czasopisma, biblioteki XIX i XX wieku. T. 7. Pod red. Haliny Kosętki, Kraków: Wydaw. Naukowe Uniwersytetu Pedagogicznego 2005, s. 65-78.

95 A. ALEKSIEWICZ, Drukarstwo w Rzeczypospolitej Krakowskiej...

96 M.in. Jerzy SNOPEK, Prowincja oświecona: kultura literacka Ziemi Krakowskiej w dobie Oświecenia 1750-1815, Warszawa: IBL PAN 1992.

97 Stanisław Adam KONDEK, Władza $i$ wydawcy: polityczne uwarunkowania produkcji książek w Polsce w latach 1944-1949, Warszawa: Biblioteka Narodowa 1993; idem, Papierowa rewolucja. Oficjalny obieg ksiązek w Polsce w latach 1948-1955, Warszawa: Biblioteka Narodowa 1999.

Roczniki Biblioteczne 60, 2016

(C) for this edition by CNS 
Dariusza Jarosza ${ }^{98}$. Pojawiły się też wydawnictwa źródłowe dotyczące działań cenzorskich, ukierunkowanych nie tyle na publikację nowości wydawniczych, ile na wycofanie istniejących już dzieł ${ }^{99}$. Uwaga badaczy skupia się też na śledzeniu tego zjawiska w różnych środowiskach zainteresowanych publikowaniem swoich dokonań ${ }^{100}$.

Ograniczenia wolności słowa drukowanego doprowadziły do ukształtowania się niezależnego ruchu wydawniczego. Jego nieoceniona rola $\mathrm{w}$ dostępie do zakazanych przez władzę polityczną publikacji była wielokrotnie podkreślana w różnych opracowaniach, także tych, które ukazywały się w trudnym czasie stanu wojennego ${ }^{101}$. Podkreślano jego antykomunistyczny charakter i zasługi dla pełnego poznania kultury piśmiennej schyłkowego okresu władzy ludowej w Polsce ${ }^{102}$.

Dzieje drukarstwa i ruchu wydawniczego to również dzieje samej książki jako wytworu pracy drukarza i wydawcy, a zwłaszcza jej kompozycji edytorsko-typograficznej. Uwaga badaczy skupiała się zarówno na cechach wydawniczych książki i jej określonych typach, jak i na poszczególnych elementach składających się na archeologię książki ${ }^{103}$. Kształtowanie się cech kompozycyjnych piętnastowiecznej książki drukowanej stało się przedmiotem uwagi M. Judy ${ }^{104}$. Badania nad literacką ramą wydawniczą starodruków prowadziła Renarda Ocieczek. Wprowadzając to pojęcie do obiegu naukowego, zwróciła na nie uwagę nie tylko badaczy dziejów kultury książki, lecz także przedstawicieli nauki o literaturze ${ }^{105}$. Dogłębną analizę kompozycji edytorsko-typograficznej książki literackiej XIX

98 Dariusz JAROSZ, Sprawozdanie Departamentu Publikacji Nieperiodycznych Głównego Urzędu Kontroli Prasy, Publikacji i Widowisk z działalności w 1968 roku, Z Badań nad Książką i Księgozbiorami Historycznymi (1) 2006, s. 95-131.

99 Cenzura w PRL. Wykaz książek podlegajacych niezwłocznemu wycofaniu 1 X 1951 r., Wrocław: Nortom 2002.

100 Zbigniew ROMEK, „Cenzura kreatywna” w PRL a środowisko naukowe historyków, Przegląd Historyczny (97) 2006, z. 1, s. 23-37.

101 Stanisław BARAŃCZAK, Niezależny ruch wydawniczy w Polsce: przeszłość i perspektywy, Rocznik Polskiego Towarzystwa Naukowego (24) 1980/81 [druk 1982], s. 175-182.

102 Stanisław SIEKIERSKI, Wydawnictwa drugiego obiegu 1976-1986, Przegląd Humanistyczny (34) 1990, nr 1, s. 21-33; Jan GOLEC, Antykomunistyczny charakter tzw. niezależnego ruchu wydawniczego w Polsce Ludowej (1981-1987), [w:] Materiaty pomocnicze do historii dziennikarstwa w Polsce Ludowej. T. 15, Warszawa: Wydaw. Uniwersytetu Warszawskiego 1991, s. 43-67.

103 O „archeologii książki” zob. Edward POTKOWSKI, Problemy kodykologii, [w:] idem, Książka i pismo w średniowieczu. Studia z dziejów kultury piśmiennej i komunikacji społecznej, Pułtusk: Akademia Humanistyczna im. Aleksandra Gieysztora 2006, s. 345-361.

104 M. JUDA, Inkunabut jako źródło historyczne, [w:] Tekst źródła: krytyka, interpretacja. Pod red. Barbary Trelińskiej, Warszawa: Wydaw. DiG 2005, s. 179-186.

105 Renarda OCIECZEK, Rama utworu, [w:] Stownik literatury staropolskiej. Pod red. Teresy Michałowskiej. Wrocław: Zakład Narod. im. Ossolińskich 1990, s. 684-688; O literackiej ramie wydawniczej $w$ ksiażkach dawnych. Pod red. Renardy Ocieczek, Katowice: Uniwersytet Śląski 1990. 
i XX wieku przeprowadził Janusz Dunin ${ }^{106}$, Alicja Matczuk zaś zbadała pod tym kątem polskie bibliografie nauk humanistycznych i społecznych ${ }^{107}$.

Badaniom poddawano też elementy składające się na archeologię dawnej książki, zwłaszcza te, które trafiły na jej karty po wynalezieniu typografii. Jednym $\mathrm{z}$ nich jest wkraczająca do jej struktury w dobie inkunabułów karta tytułowa ${ }^{108}$. Innym, właściwym tylko drukowanej formie książki, elementem jest sygnet drukarski. Reprintowe edycje sygnetów drukarzy i księgarzy wsparte zostały badaniami Katarzyny Krzak-Weiss, które pokazały tkwiący w nich ogromny potencjał badawczy ${ }^{109}$. Kolejnym charakterystycznym dla dawnej polskiej książki drukowanej elementem są stemmata - struktury słowno-obrazowe, w których główną rolę odgrywały motywy heraldyczne. Ze względu na swoją budowę oraz miejsce i rolę w dawnej książce przykuwały uwagę nie tylko bibliologów, lecz także historyków i literaturoznawców ${ }^{110}$.

Nieodłączną częścią typografii jest pismo. Istota wynalazku Jana Gutenberga — udoskonalanie technik wytwarzania czcionki drukarskiej - to kolejny nurt badań ${ }^{111}$. Mieszczą się w nim prace nad zasobami typograficznymi szesnastowiecznych oficyn funkcjonujących na ziemiach polskich ${ }^{112}$. Badacze, stosując metodę typograficzną, nie tylko identyfikują ich wytwory, lecz także starają się dać odpowiedź na proweniencję pisma i jego cechy charakterystyczne odnośnie do poszczególnych typografii. Pismo stanowi jednak nie tylko pewien zasób znaków graficznych i system ich używania dla oddania mowy i myśli ludzkiej w celu ich utrwalenia i przekazania w czasie i przestrzeni, lecz także fakt historyczny. $\mathrm{W}$ związku z tym podlega ono różnorakim zmianom wynikającym ze zjawisk o charakterze kulturalnym, artystycznym, społecznym, wyznaniowym, politycznym, gospodarczym i technicznym. W takim kontekście i w takiej perspektywie podjęła badania nad pismem drukowanym w dawnej Polsce M. Juda ${ }^{113}$.

106 Janusz DUNIN, Rozwój cech wydawniczych polskiej książki literackiej XIX-XX wieku, Łódź: Uniwersytet Łódzki 1982.

107 Alicja MATCZUK, Polskie bibliografie nauk humanistycznych i społecznych do roku 1989. Historia i metodyka, Lublin: Wydaw. UMCS 2014, s. 349-386.

108 M. JUDA, Karta tytułowa staropolskiej książki drukowanej, Odrodzenie i Reformacja w Polsce (46) 2002, s. 67-78.

109 Sygnety polskich drukarzy, księgarzy i nakładców: zbiór podobizn i oryginalnych odbić. Oprac. Kazimierz Hałaciński, Kazimierz Piekarski. Z. 1-3, Warszawa: Wydaw. Artystyczne i Filmowe 1986 [reprint]; Katarzyna KRZAK-WEISS, Polskie sygnety drukarskie od polowy XV do połowy XVII wieku, Poznań: Wydaw. Poznańskie Studia Polonistyczne 2006.

${ }^{110}$ M.in. Franciszek PILARCZYK, Stemmata $w$ drukach polskich XVI wieku, Zielona Góra: Wydaw. WSP w Zielonej Górze 1982; Bartłomiej CZARSKI, Stemmaty w staropolskich ksiązkach, czyli Rzecz o poezji heraldycznej, Warszawa: Muzeum Pałacu w Wilanowie 2012; M. JUDA, Stemmata w drukach lubelskich XVII-XVIII wieku, Bibliotheca Nostra (38) 2014, nr 4, s. 97-110.

111 Zob. J. PIROŻYŃSKI, Johannes Gutenberg i początki ery druku, Warszawa: PWN 2002.

112 Zob. Polonia typographica...

113 M. JUDA, Pismo drukowane w Polsce XV-XVIII wieku, Lublin: Wydaw. UMCS 2001. 
Osiągnięciom polskiej typografii od przełomu XIX i XX wieku do wybuchu drugiej wojny światowej wiele studiów poświęcił Janusz Sowiński. Dokonując analizy i oceny jej dorobku, zwrócił też uwagę na to, co się działo w obszarze pisma. Na uwagę zasługuje podniesiona przez niego kwestia stworzenia polskiej czcionki, oddającej cechy i walory rodzimej pisowni i ortografii ${ }^{114}$. Nie tylko teoretykom, lecz także praktykom sztuki drukarskiej służą liczne opracowania dotyczące pisma autorstwa Romana i Andrzeja Tomaszewskich ${ }^{115}$. Historyczne już tylko znaczenie ma zespołowo opracowany słownik encyklopedyczny odnoszący się do polskiego drukarstwa i grafiki książki ${ }^{116}$.

W kształcie edytorskim książki istotną rolę odgrywa jej oprawa graficzna. Powstałe do połowy lat 70. ubiegłego wieku badania w tym zakresie w odniesieniu do szesnastego stulecia przedstawiła Ewa Chojecka ${ }^{117}$. Wskazała na jej stylistykę, stopień podporządkowania słowu drukowanemu, na inspiracje zewnętrzne oraz rodzime rozwiązania. Dokonania kolejnych lat mają w zasadzie charakter przyczynków dopełniających wcześniejsze osiągnięcia. Tego rodzaju opracowań brakuje wobec książki powstałej w następnym wieku. Odnoszą się one albo do określonych ośrodków drukarskich, albo do pewnego rodzaju wydawnictw lub też poszczególnych elementów książki ${ }^{118}$. Próbę analizy i oceny strony estetycznej, w tym również materiału zdobniczo-ilustracyjnego druków osiemnastowiecznych, podjął Zdzisław Staniszewski ${ }^{119}$.

Dzięki badaniom Andrzeja Banacha i Janiny Wiercińskiej poznano wiele aspektów zdobnictwa książki dziewiętnastowiecznej, lecz do pełnego zbadania

114 M.in. J. SOWIŃSKI, Sztuka typograficzna Młodej Polski, Wrocław: Ossolineum 1982; idem, Adam Póttawski. Typograf artysta, Wrocław: Ossolineum 1988; idem, Typografia wytworna w Polsce 1919-1939, Wrocław: Ossolineum 1995.

115 M.in. Roman TOMASZEWSKI, Materiaty do bibliografi na temat czytelności pism drukarskich, Warszawa: Wydaw. Katalogów i Cenników 1973; idem, Klasyfikacja pism drukarskich ART, [w:] Z badań nad dawną ksiązką... Cz. 2, s. 663-676; Andrzej TOMASZEWSKI, Pismo drukarskie, Wrocław: Ossolineum 1989; idem, Leksykon pism drukarskich, Warszawa: Wydawnictwo Krupski i S-ka 1996.

116 Współczesne polskie drukarstwo i grafika ksiązki. Mały słownik encyklopedyczny, Wrocław: Ossolineum 1982.

117 Ewa CHOJECKA, Znaczenie kulturowe grafiki polskiej XVI wieku, [w:] Dawna ksiażka..., s. 86-114.

118 Anna TREIDEROWA, Ze studiów nad ilustracja wydawnictw krakowskich $w$ wieku XVII, Rocznik Biblioteki PAN w Krakowie (14) 1968, s. 10-35, il.; eadem, Przyczynek do zagadnień zwiąków polsko-niderlandzkich w zakresie grafiki ilustracyjnej w XVII wieku, Rocznik Biblioteki PAN w Krakowie (16) 1970, s. 5-17; Alicja KURKOWA, Grafika ilustracyjna gdańskich druków okolicznościowych XVII wieku, Wrocław: Zakład Narod. im. Ossolińskich 1979; Małgorzata KOMZA, Zdobione karty tytutowe (Wprowadzenie do typologii na przyktadzie siedemnastowiecznej książki gdańskiej), Studia o Książce (8) 1978, s. 51-80.

119 Zdzisław STANISZEWSKI, Estetyka polskiego druku książkowego XVIII wieku. Zarys problematyki, Ze Skarbca Kultury 1960, z. 1 (12), s. 120-164. 
tej problematyki potrzeba jeszcze wielu studiów ${ }^{120}$. Szczególną uwagę badaczy budziła sztuka zdobnicza przełomu XIX i XX wieku - i to zarówno w odniesieniu do książki, jak i czasopism literacko-artystycznych ${ }^{121}$. Pod tym względem interesowano się też edycjami dzieł określonych autorów lub też osiągnięciami poszczególnych artystów ${ }^{122}$.

W badaniach nad dziejami i współczesnymi aspektami sztuki typograficznej i jej wytworem — książką — istotne miejsce zajmuje problem jej właściwego kształtu edytorskiego. Odpowiednia realizacja wydawnicza dzieła piśmienniczego wpływa nie tylko na jej kształt estetyczny, lecz także podnosi jej walor informacyjny i komunikacyjny. Wokół tych zagadnień koncentrowały się, między innymi, badania Teodora Zbierskiego i Karola Głombiowskiego ${ }^{123}$. O wadze problematyki odnoszącej się do sztuki książki w aspekcie teoretycznym i praktycznym, w kontekście edytorstwa tradycyjnego i nowych technologii elektronicznych świadczy zbiór studiów będących pokłosiem konferencji naukowej poświęconej sztuce książki ${ }^{124}$.

Na uwagę zasługują również studia dotyczące zawodu drukarza i wydawcy $^{125}$. Organizacji zawodowej dawnych typografów poświęcili swoją uwagę Barbara Bogusławska i Józef Szczepaniec ${ }^{126}$, a wydawcom odrodzonej Polski — Leon Marszałek ${ }^{127}$. Profesjonalny charakter tej grupy zawodowej uwidaczniał się — między innymi - w publikowaniu fachowych czasopism. Zwróciła na nie uwagę jako na istotne źródło bibliologiczne Hanna Tadeusiewicz ${ }^{128}$.

120 Andrzej BANACH, Polska ksiażka ilustrowana 1800-1900, Kraków: Wydaw. Literackie 1959; Janina WIERCIŃSKA, Z problematyki zdobnictwa książkowego lat 90-tych XIX w., [w:] Sztuka około 1900. Materiały sesji Stowarzyszenia Historyków Sztuki, Kraków, grudzień 1967, Kraków: PWN 1969, s. 223-243; eadem, Sztuka i książk, Warszawa: PWN 1986.

121 Katarzyna KULPIŃSKA, Szata graficzna młodopolskich czasopism literacko-artystycznych, Warszawa: DiG 2005.

122 Elżbieta SKIERKOWSKA, Wyspiański, artysta książki, Wrocław: Ossolineum 1960; M. KOMZA, Mickiewicz ilustrowany, Wrocław: Ossolineum 1987.

123 M.in.: Teodor ZBIERSKI, Semiotyka ksiażki, Wrocław: Ossolineum 1978; K. GŁOMBIOWSKI, Książka w procesie komunikacji społecznej, Wrocław: Zakład Narod. im. Ossolińskich 1980.

124 Sztuka ksiażki. Historia - teoria - praktyka. Pod red. M. Komzy, Wrocław: Wydaw. Uniwersytetu Wrocławskiego 2003.

125 O potrzebie takich badań zob. E. GONDEK, Zawód drukarza i technologia druku w bibliologii i poza jej zakresem, [w:] Teoretyczne zagadnienia bibliologii i informatologii. Studia i szkice. Pod red. E. Gondek, Katowice: Wydaw. Uniwersytetu Śląskiego 2015, s. 53-74.

126 Barbara BOGUSŁAWSKA, Kongregacja Towarzyszy Kunsztu Drukarskiego. Warszawa: Druk Szkoły Przemysłu Graficznego 1929; J. SZCZEPANIEC, Towarzysze kunsztu drukarskiego $w$ Warszawie drugiej połowy XVIII wieku w świetle aktów wyzwolenia i opinii pracodawców, Roczniki Biblioteczne (6) 1962, z. 3/4, s. 171-186.

127 Leon MARSZAŁEK, Polskie Towarzystwo Wydawców Ksiażek w latach 1921-1945, Rocznik Biblioteki Narodowej (15) 1979 [druk 1983], s. 275-298.

128 H. TADEUSIEWICZ, Czasopisma drukarskie galicyjskie z lat 1872-1900 jako źródła do dziejów drukarstwa polskiego XIX w., Studia o Książce (11) 1981, s. 113-152; eadem, Drukarstwo 
Praktyczny oraz teoretyczny wymiar mają prace odnoszące się do procesu publikacyjnego określonego typu wydawnictw. Na potrzeby i wymagania w tym względzie wobec książki naukowej wskazał Czesław Dejnarowicz ${ }^{129}$. Efektem pracy zespołowej jest wydawnictwo poświęcone książce szkolnej ${ }^{130}$.

Przedstawiony przegląd badań nad dziejami ruchu wydawniczego w Polsce nie wyczerpuje pełnego katalogu zagadnień. Pozwala jednak na wskazanie zadań stających przed środowiskiem bibliologicznym ${ }^{131}$. W dalszym ciągu istnieje potrzeba rejestracji polskiej produkcji wydawniczej, zwłaszcza od początku XIX wieku do roku 1939. Podobnie jak w każdej innej dyscyplinie rozwój badań bibliologicznych wymaga edycji źródeł do dziejów ruchu wydawniczego w Polsce. Warto kontynuować prace nad procesami tworzenia i produkcji książki, nad wytwórcami książki jako grupą społeczną i zawodową, nad programowaniem i prognozowaniem wydawniczym w kontekście zmian politycznych, społecznych, kulturalnych, wyznaniowych, technologicznych i innych. Z bibliologicznego punktu widzenia należy również przyjrzeć się zakresowi i charakterowi pracy wykonywanej przez redaktora-wydawcę książki, i to zarówno w ujęciu historycznym, jak i współczesnym. Wydaje się, że badania nad zasobami typograficznymi poszczególnych warsztatów, grafiką książkową, realizacją wydawniczą dzieł piśmienniczych powinny zmierzać do ustalenia swoistego kanonu estetycznego polskiej książki drukowanej na różnych etapach jej rozwoju. Celem, ku któremu warto dążyć, jest opracowanie syntezy dziejów ruchu wydawniczego w Polsce.

MARIA JUDA

\section{POLISH POST-WAR RESEARCH INTO THE HISTORY OF PUBLISHING IN POLAND: ACHIEVEMENTS AND RESEARCH PROPOSALS}

\section{Summary}

The history of publishing in Poland encompasses many issues associated with the emergence and dissemination of printed books. Of fundamental significance to the study of these issues are the records of the publishing output: while we have nearly complete - though requiring further exploration - records of this output for 15th-18th centuries, documented in bibliographies and catalogues, the situation is worse when it comes to the 19th and 20th centuries, until the outbreak of the Second World War. In this respect what we need is not only a continuation, but a radical

polskie drugiej połowy XIX wieku w świetle fachowych czasopism drukarzy z lat 1872-1900. Problematyka zawodowa i społeczna, Łódź: Uniwersytet Łódzki 1982.

129 Czesław DEJNAROWICZ, Literatura naukowa - uczeni - wydawcy, Warszawa: PWN 1980; idem, Przyszłość książki naukowej wąskospecjalistycznej. Perspektywy i trudności, Nauka Polska (28) 1980, nr 3/4, s. 149-159.

${ }^{130}$ Książka szkolna. Opracowanie i edytorstwo, Warszawa: Wydaw. Szkolne i Pedagogiczne 1980.

131 O zadaniach badawczych wobec dawnego drukarstwa zob. M. JUDA, Dawne drukarstwo jako aktualne zadanie badawcze, [w:] Teoretyczne zagadnienia..., s. 43-51. 
intensification of bibliographic work. This concerns works published in the Latin, Cyrillic, Hebrew and Greek scripts as well as musical notation. Polish book scholars devoted a lot of attention to the beginnings of printing in Poland; the historiography concerning various typographic workshops located in the former Polish-Lithuanian Commonwealth is rich, though it still requires further extensive studies. The scholars were also interested in phenomena influencing the content structure of printed publications, like publishing privileges (in the former Polish-Lithuanian Commonwealth), censorship as well as restrictions imposed by the partitioning powers and later by Poland's communist authorities, as a result of which Polish publications had to be printed abroad and an independent publishing movement emerged. The scholars' research interests also focused on books as products of the work of printers and publishers, on the publication of written works. They focused both on the various components of the book (title page, printer's signet, stemmata etc.) and on its editorial composition as a whole.

The scholars' undoubted achievements in their studies of the history of publishing in Poland are significant, yet in many areas they need to be continued and expanded (an important task is an edition of sources for the study of the history of Polish publishing), and concentrated on the phenomena that stem from developmental tendencies in modern book studies.

KEY WORDS: bibliology, historical bibliology, history of the book, printing, publishing, editing 